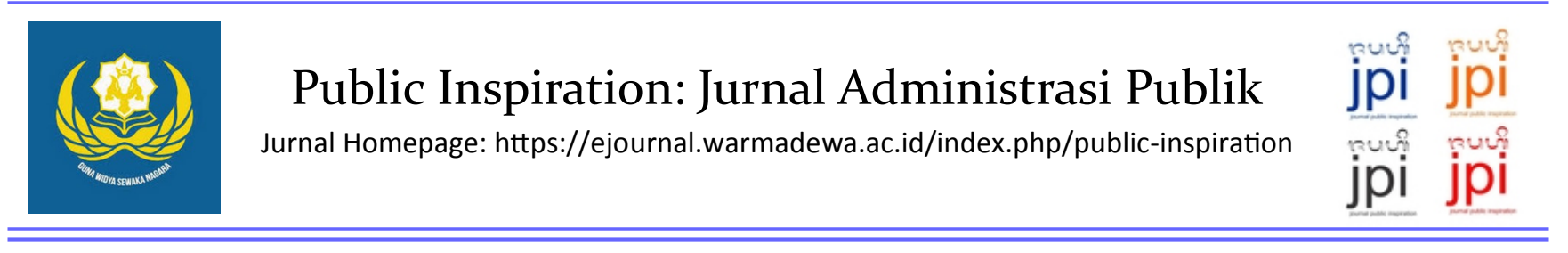

\title{
Aktivitas Komunikasi Ritual Pada Tradisi Omed-Omedan Banjar Kaja Sesetan Denpasar Bali
}

\author{
Ni Putu Ayudiah Sriwidya Naraswari* dan Agus Aprianti \\ Universitas Telkom, JL. Telekomunikasi Terusan Buah Batu, Bandung, Indonesia \\ Email:ayudiah37o@gmail.com
}

How to Cite: Naraswari, N, P, A, S., Aprianti, A. (2021). Aktivitas Komunikasi Ritual Pada Tradisi Omed-Omedan Banjar Kaja Sesetan Denpasar Bali. Public Inspiration: Jurnal Administrasi Publik, 6 (1): 19-28. DOI: https:// doi.org/10.22225/pi.6.1.2021.19-28

\begin{abstract}
Bali is an island which has a lot of customs and unique traditions. One of the unique traditions is Omed-Omedan. It is a tradition of attraction carried out by members of Banjar Kaja. The aim of this attraction is to establish friendship among the others. The research purpose is to explain the ritual communication activities that occur in the implementation of the Omed-Omedan Tradition. In this study, the ethnographic study method of communication in qualitative research uses the constructivism paradigm. In this study the data were obtained by in-depth interviews, literature study and field observations. The results obtained are then analyzed, explained, and concluded. Then the conclution is of this research is the communicative situations that occurred in the tradition, is sacred, joy, a thick magical aura, and intimacy. The communicative events that occurred started with praying together, Dharma Santi, the main event, and the ritual procession. Communicative action describes the entire verbal and non-verbal communication as well as the existing symbols. The three elements of the research results are the keys in describing to discusses how communication activities and ritual communication processes that occur in the Omed-Omedan Tradition in Banjar Kaja Sesetan, Denpasar City.
\end{abstract}

Keywords: communication activities; omed-omedan tradition; ritual communication

\begin{abstract}
Abstrak
Bali merupakan pulau yang memiliki banyak sekali adat dan tradisi yang unik. Salah satu tradisi yang unik adalah OmedOmedan. Merupakan tradisi atraksi yang dilakukan oleh anggota Banjar Kaja. Tujuan dari atraksi ini adalah untuk menjalin persahabatan antar sesama. Tujuan penelitian adalah untuk menjelaskan kegiatan komunikasi ritual yang terjadi dalam pelaksanaan Tradisi Omed-Omedan. Dalam penelitian ini, metode studi etnografi komunikasi dalam penelitian kualitatif menggunakan paradigma konstruktivisme. Dalam penelitian ini data diperoleh dengan wawancara mendalam, studi pustaka dan observasi lapangan. Hasil yang diperoleh kemudian dianalisis, dijelaskan, dan disimpulkan. Maka kesimpulan dari penelitian ini adalah situasi komunikatif yang terjadi dalam tradisi, bersifat sakral, kegembiraan, aura magis yang kental, dan keakraban. Acara komunikatif yang terjadi diawali dengan doa bersama, Dharma Santi, acara inti, dan prosesi ritual. Tindakan komunikatif menggambarkan keseluruhan komunikasi verbal dan nonverbal serta simbolsimbol yang ada. Ketiga unsur hasil penelitian tersebut menjadi kunci dalam mendeskripsikan untuk membahas bagaimana aktivitas komunikasi dan proses komunikasi ritual yang terjadi dalam Tradisi Omed-Omedan di Banjar Kaja Sesetan Kota Denpasar.
\end{abstract}

Kata Kunci: kegiatan komunikasi; tradisi omed-omedan; komunikasi ritual 


\section{Pendahuluan}

Bali adalah salah satu dari 34 provinsi di Indonesia yang memiliki beragam kebudayaan unik yang memiliki banyak tradisi didalamnya. Salah satu kota di provinsi Bali yang memiliki berbagai tradisi unik yaitu kota Denpasar. Kota Denpasar memiliki beberapa tradisi unik yang tidak dimiliki oleh daerah lainnya, tradisi ini dilakukan pada hari-hari tertentu yang memiliki makna dan tujuan tersendiri. Seperti yang dilansir pada Bali.Tribunnews Denpasar memiliki tiga tradisi unik yang patut untuk kamu ketahui dan tonton (Supartika 2018). Tiga tradisi tersebut memiliki keunikannya masingmasing dan dilakukan secara turun temurun.

Salah satu contoh tradisi yang ada dan sudah dilakukan secara turun-temurun yaitu Tradisi Omed-Omedan. Omed-Omedan merupakan salah satu tradisi yang dilakukan oleh truna-truni (mudamudi) Banjar Kaja Sesetan Kota Denpasar. Banjar Kaja merupakan salah satu banjar adat yang berada di dalam wilayah kelurahan Desa Sesetan Kota Denpasar Bali, Kaja merupakan Bahasa bali yang memiliki arti utara yang mana berarti Banjar Kaja merupakan wilayah paling utara dari desa Sesetan. Tradisi Omed-Omedan ini kini lebih dikenal sebagai tradisi ciuman masal yang dilakukan oleh trunatruni Banjar Kaja Sesetan setiap tahunnya. Seperti yang dilansir pada Brilio.net Omed-Omedan sendiri dilakukan sehari setelah Nyepi. Omed-Omedan dilakukan sebagai ajang untuk menjalin tali persaudaraan antara truna-truni banjar Kaja Sesetan. Pada dasarnya Omed-Omedan dalam Bahasa bali berarti Tarik-menarik yang mana dilakukan antar truna-truni (muda-mudi), dalam pelaksanannya truna-truni (muda-mudi) saling menarik pinggul dalam pelaksaan tradisi ini (Wahyuningsih 2019).

Tradisi Omed-Omedan merupakan tradisi yang menjadi salah satu ciri khas bagi Provinsi Bali khususnya Desa Sesetan. Tradisi ini merupakan suatu bentuk upaya masyarakat Banjar Kaja untuk mencegah marabahaya yang akan datang jika tradisi ini tidak dilaksankan. Selain itu, dengan tradisi ini para truna-truni (muda-mudi) Banjar Kaja bisa lebih mengakrabkan diri satu dengan yang lainnya juga memperkuat rasa asah, asih, dan asuh antar warga. Masyarakat Banjar Kaja, Desa Sesetan, hingga saat ini percaya bahwa Tradisi Omed-Omedan harus mereka lakukan, lestarikan dan tetap mereka jaga hingga tahun-tahun yang akan mendatang.

Dengan keunikan tradisi yang dimilikinya, dalam rangkaian pelaksanaan Tradisi Omed-Omedan terdapat beberapa ritual yang dilakukan sebelum dimulainya tradisi ini. Seperti yang diucapkan oleh I Gusti Ngurah Oka Putra Ritual pada penelitian terdahulu yang berjudul "Perspektif Sosio-Budaya dan Religius Terhadap Tradisi Omed-Omedan di Banjar Kaja, Desa Pekraman Sesetan, Kota Denpasar, Bali" (Cahyadinata 2013). Yang dilakukan pertama sebelum dilakukannya Tradisi Omed-Omedan. Diawali dengan persembahyangan bersama antar peserta Omed-Omedan untuk memohon keselamatan dan kelancaran selama acara berlangsung, kemudian dibuka dengan tari-tarian sakral dan ditutup dengan persembahyangan untuk mengucapka terimakasih kepada Ida Sang Hyang Widhi Wasa Tuhan Yang Maha Esa, karena acara Omed-Omedan telah diberikan kelancaran (Cahyadinata 2013). Pada penelitian ini juga dibahas strategi yang dilakukan masyarakat setempat untuk mempertahankan tradisi ini yaitu dengan memberikan pengarahan juga sosialisasi kepada truna-truni (muda-mudi) setempat tentang betapa pentingnya menjaga dan melestarikan tradisi yang ada.

Komunikasi ritual berkaitan dengan sistem religi yang dianut dan dipercaya oleh sekelompok masyarakat tertentu. Kegiatan ritual yang dilakukan pada Tradisi Omed-Omedan ini merupakan salah satu bentuk wujud syukur masyarakat Banjar Kaja Desa Sesetan kepada Ida Sang Hyang Widhi Wasa Tuhan Yang Maha Esa karena selalu dilindungi dan lingkungan mereka dijauhkan dari marabahaya. Pakem-pakem dalam menjalani tradisi ini pun jelas, tidak seperti yang banyak dibicarakan bahwa tradisi ini terkesan porno atau tidak sesuai dengan norma. Menurut I Gusti Ngurah Oka Putra selaku sesepuh Banjar Kaja Sesetan dalam wawancara yang dilakukan dengan peneliti, "Omed-Omedan memiliki pakem tersendiri tidak ada yang Namanya tradisi ciuman masal. Tradisi ini memiliki pakem yang mana mengatur peletakan kedua tangan saat pelaksanaannya, yakni tangan kanan berada pada 
bahu dan tangan kiri berada pada ketiak pasangan. Selain itu ditekankan ciuman tidak diperbolehkan, namun dalam pelaksanaannya sering kali terjadi gesekan antar pipi dan itu wajar terjadi". I Gusti Ngurah Oka Putra menekankan bahwa tradisi ini bukan merupakan tradisi porno apalagi tradisi ciuman masal. Truna-truni (muda-mudi) setempat pun ikhlas dalam menjalani tradisi ini, karena mereka percaya tradisi ini bila dilakukan dengan tulus iklhas niscaya memiliki dampak baik yang positif bagi masyarakat khususnya masyarakat Bajar Kaja, Desa Sesetan.

Tradisi ini tidak boleh dihilangkan karena merupakan budaya yang di lakukan dan dipercayai oleh masyarakat setempat. Tradisi Omed-Omedan merupakan sebuah tradisi yang terbuka untuk umum siapa saja boleh hadir dan menonton dari berbagai kalangan. Berdasarkan observasi yang telah penulis lakukan terdapat banyak kesalahpahaman terkait tradisi ini yang terjadi di lapangan. Sehingga penulis ingin mengetahui dan menggali kembali makna dan aktivitas komunikasi yang terjadi dari diadakannya Tradisi Omed-Omedan dan ritual yang ada didalamnya. Aktivitas komunikasi sama artinya dengan mengidentifikasikan peristiwa, situasi, dan tindakan yang terjadi pada saat pelaksanaan tradisi berlangsung.

\section{Tinjauan Pustaka}

\section{Komunikasi Ritual}

Suatu komunitas atau kelompok sosial seringkali melakukan beberapa upacara atau kegiatan berbeda sepanjang tahun dalam sepanjang hidupnya, yang disebut para antropolog sebagai rites of passage, mulai dari rangkaian upacara dalam kelahiran, ulang tahun, pertunangan, pernikahan, hingga upacara kematian. Ritus-ritus lain seperti berdoa (sholat, sembahyang, misa, matur sembah) upacara atau perayaan keagamaan seperti Natal, Idul Fitri, dan Nyepi juga adalah komunikasi ritual. Dalam beberapa upacara tersebut orang-orang cenderung menyebutkan kata-kata atau menampilkan perilakuperilaku simbolik. Individu yang turut serta berpartisipasi dalam sebuah komunikasi ritual tersebut menegaskan kembali komitmen yang mereka lakukan dan percaya pada tradisi keluarga, komunitas atau kelompok, suku, bangsa, negara, ideologi, atau agama mereka. Sampai kapanpun ritual tampaknya akan tetap menjadi kebutuhan manusia yang percaya akan maknanya. Biarpun memiliki bentuk yang berubah-ubah namun demi pemenuhan jati dirinya sebagai individu, sebagai anggota komunitas sosial, dan sebagai salah satu unsur dari alam semesta. (Mulyana 2013)

Komunikasi ritual kadang-kadang bersifat mistik dan tidak dapat dimengerti oleh orang-orang diluar lingkungan tersebut, itulah yang terjadi dengan penelitian yang diteliti peneliti saat ini. Tradisi Omed-Omedan memiliki beberapa ritual-ritual yang sulit dimengerti oleh orang di luar lingkungan Banjar Kaja Sesetan. Pada penelitian ini menggunakan komunikasi ritual peneliti akan menjelaskan makna-makna ritual yang dilakukan oleh masyarakat Banjar Kaja Sesetan pada Tradisi OmedOmedan.

\section{Etnografi Komunikasi}

Dalam etnografi komunikasi yang menjadi fokus perhatian adalah bagaimana perilaku komunikasi yang terjadi dalam suatu tema kebudayaan tertentu, sehingga bukan keseluruhan perilaku tidak seperti dalam etnografi. Kuswarno menjelaskan yang dimaksud dengan perilaku komunikasi menurut ilmu komunikasi adalah tindakan atau kegiatan seseorang, kelompok, atau khalayak ketika terlibat dalam proses komunikasi (Kuswarno,2011). Etnografi komunikasi berperan sebagai salah satu metode dalam menjelaskan perilaku komunikasi yang terjadi pada objek penelitian yang dilakukan peneliti saat ini. Etnografi komunikasi pada penelitian yang dilakukan peneliti saat ini tidak membahas keseluruhan perilaku melainkan lebih kepada tindakan, situasi dan peristiwa komunikatif yang terjadi di lapangan secara lebih mendalam.

Hasil dari sebuah penelitian etnografi komunikasi memuat penjelasan pemolaan komunikasi melalui beberapa kategori ujaran. Kategori ujaran merupakan proses pengelompokan peristiwa dan 
Public Inspiration: Jurnal Administrasi Publik, 6 (1) (2021), 22

Aktivitas Komunikasi Ritual Pada Tradisi Omed-Omedan Banjar Kaja Sesetan Denpasar Bali

tindak komunikatif yang terjadi ke dalam setting peristiwa tertentu yang bisa berbeda, atau hubungan antara komponen-komponen komunikasi dalam setting komunikasi tertentu (Kuswarno, 2011:38)

\section{Aktivitas Komunikasi}

Menurut Hymes (dalam Kuswarno, 2011:41) untuk mendeskripsikan atau menjelaskan dan menganalisa aktivitas komunikasi dalam etnografi komunikasi, diperlukan pemahaman dan pengertian mengenai unit-unit diskrit aktivitas komunikasi. Unit-unit diskrit aktivitas komunikasi tersebut yaitu sebagai berikut:

\section{Situasi Komunikatif}

Situasi komunikatif merupakan konteks terjadinya suatu komunikasi. Sebuah peristiwa komunikasi terjadi dalam satu situasi komunikasi dan peristiwa itu mengandung satu atau lebih tindak komunikasi didalamnya. Situasi terjadinya peristiwa bisa sama walaupun lokasi kejadiannya berubah atau berbeda, atau bisa juga berubah dalam lokasi yang sama apabila aktivitas-aktivitas yang berbeda berlangsung di tempat tersebut pada saat yang berbeda. Situasi yang sama bisa mempertahankan konfigurasi umum yang konsisten pada aktivitas dan ekologi yang sama di dalam komunikasi terjadi, meskipun terdapat perbedaan dalam jenis interaksi yang terjadi disana.

\section{Peristiwa Komunikatif}

Keseluruhan perangkat komponen yang utuh yang dimulai dengan tujuan umum komunikasi, topik umum yang sama, dan melibatkan partisipan yang secara umum menggunakan varietas Bahasa yang sama, mempertahankan tone yang sama, dan kaidah-kaidah yang sama untuk interaksi dalam setting yang sama. Sebuah peristiwa komunikatif dinyatakan telah berakhir, apabila terjadi perubahan partisipan, adanya periode hening, atau perubahan posisi tubuh.

\section{Tindakan Komunikatif}

Tindak komunikatif merupakan salah satu bagian dari peristiwa komunikatif dengan fungsi interaksi tunggal, seperti pernyataan, permohonan, perintah, dan dapat bersifat verbal ataupun nonverbal. Sehingga dalam tindak komunikatif termasuk didalamnya bentuk komunikasi verbal dan non verbal. Dalam konteks komunikatif, bahkan diam pun merupakan tindak komunikatif konvensional.

Menurut etnografi komunikasi, aktivitas tidak bergantung pada adanya pesan, komunikator, komunikate, media, efek, dan sebagainnya. Sebaliknya yang dimaksud dengan aktivitas komunikasi adalah aktivitas yang khas kompleks dimana didalamnya terdapat peristiwa-peristiwa khas komunikasi yang melibatkan tindak-tindak komunikasi tertentu dan dalam konteks komunikasi yang tertentu pula (Kuswarno 2011). Aktivitas komunikasi berperan sebagai sebuah konsep dalam penelitian yang sedang dilakukan, dengan aktivitas komunikasi peneliti akan menjelaskan sebuah objek yang diamati berdasarkan peristiwa, situasi, dan tindakan komunikatif yang terjadi.

\section{Metode}

Dalam penelitian yang dilakukan peneliti saat ini, paradigma yang digunakan adalah pardigma konstruktivisme. Paradigma konstruktivisme melihat bahwa fakta atau realita yang ada merupakan hasil konstruksi atau bentukan dari manusia itu sendiri. Kenyataan tersebut terjadi sebagai hasil bentukan dari kemampuan berpikir seseorang atau individu. Arifin (dalam Yanti, Putu Feby Sukma \& Nurhayati, 2018). Metode yang digunakan adalah metode kualitatf dengan pendekatan etnografi komunikasi. Karena menggunakan studi etnografi komunikasi dapat menggambarkan, menjelaskan, membangun hubungan dari berbagai kategori dan data yang ditemukan. Hal ini sesuai dengan tujuan dari studi etnografi komunikasi, yaitu untuk menggambarkan, menganalisis, dan menjelaskan perilaku dari suatu kelompok sosial (Kuswarno, 2011:86). Subjek dalam penelitian ini adalah sesepuh Banjar Kaja, Kelihan (tetua) adat Banjar Kaja, ketua muda-mudi Banjar Kaja, dan salah satu anggota muda- 
mudi Banjar Kaja. Beberapa subjek tersebut dipilih karena memiliki pengalaman serta pengetahuan terkait dengan objek penelitian yaitu Tradisi Omed-Omedan di Banjar Kaja Sesetan.

\section{Hasil Penelitian Dan Pembahasan}

Tradisi Omed-Omedan sudah dilakukan lebih dari 100 tahun yang lalu. Tradisi ini pertama kali dilakukan pada abad 17 menjelang 18 dan dilakukan hingga saat ini. Tradisi Omed-Omedan hingga saat ini masih menjadi perdebatan. Dengan banyaknya selentingan miring yang mengatakan bahwa tradisi ini merupakan tradisi 'cium-ciuman' yang mengandung konten pornografi. Namun ditengah banyaknya selentingan yang berkembang tradisi ini tetap dilakukan hingga kini. Tradisi Omed-Omedan hanya dilakukan oleh masyarakat Banjar Kaja Desa Sesetan.

Seiring berjalannya waktu kegiatan tersebut selalu dilakukan dan perlahan dikemas sedemikian rupa menjadi sebuah kegiatan yang diberi nama Omed-Omedan yang berarti Tarik menarik. Hingga pada tahun 1984 terdapat selentingan negative mengenai tradisi ini yang membuat I Gusti Ngurah Oka Putra selaku salah satu keturunan Puri Oka memutuskan untuk meniadakan tradisi ini. Namun terjadi suatu kejadian aneh yang mana terdapat dua ekor babi besar yang melakukan pertarungan di arena permainan dan menghilang begitu saja. Setelah dilaksanakan beberapa ritual keagamaan didapatkan hasil bahwa peristiwa tersebut merupakan pertanda bahwa Tradisi ini merupakan kehendak leluhur dan harus dilaksanakan. Yang kemudian hingga saat ini Tradisi Omed-Omedan tetap dilaksankan.

Dilihat dari sisi nalar manusia alasan dilakukannya tradisi ini yaitu sebagai ajang untuk melestarikan tradisi dan menjalin silahturahmi antar warga banjar khususnya Truna-truni (muda-mudi) Banjar Kaja Sesetan. Namun jika dilihat dari sisi spiritual alasan Tradisi Omed-Omedan tetap dilaksanakan hingga saat ini yaitu sebagai salah satu cara untuk menghindari mara bahaya, karena masyarakat Banjar Kaja Sesetan memiliki petapakan yang disungsung (disembah) di Pura yaitu Barong bangkal yang disebut Ida Ratu Gede Bangkal Putih (Figur Babi) yang mana pada tahun 1984 terdapat dua babi yang berkelahi di arena berlangsungnya Omed -Omedan. Yang mana setelah itu dilakukan upacara secara sipiritual kepada orang yang mapiunus (kesurupan) tentang kejadian aneh tersebut. Jawaban singkat diberikan bahwa Tradisi Omed-Omedan adalah kehendak sesuhunan (Manifestasi Tuhan) yang berstana di Pura Banjar Kaja. Oleh karena itu masyarakat Banjar Kaja Sesetan beranggapan tradisi ini mengandung unsur niskala (tidak berwujud) yang harus dilestarikan dan disusun dengan lebih rapi untuk diwariskan kepada generasi penerus selanjutnya.

Terdapat beberapa ritual sebelum dan sesudah pelaksanaan Tradisi Omed-Omedan yang mana memiliki sedikit perbedaan dengan Tradisi lain dari beberapa daerah. Dalam pelaksanaannya Tradisi Omed-Omedan dilaksanakan di depan Banjar Kaja Sesetan. Urutan kegiatan yang dilakukan dalam Tradisi Omed-Omedan yaitu:

Tabel 1.

Tata Cara Pelaksanaan Tradisi Omed-Omedan

\begin{tabular}{|c|c|c|}
\hline No & Prosesi Upacara & Keter ang an \\
\hline 1 & Mepejati & $\begin{array}{l}\text { Menghaturkan Banten Pejati sebagai } \\
\text { bentuk permohonan }\end{array}$ \\
\hline 2 & $\begin{array}{l}\text { Persembahyangan } \\
\text { Bersama }\end{array}$ & $\begin{array}{l}\text { Persembahyangan menggunakan } \\
\text { sarana chupa dan bunga yang } \\
\text { dipimpin oleh Jero Pemangku }\end{array}$ \\
\hline 3 & Dharma Santi & $\begin{array}{l}\text { Kegiatan yang dilakukan untuk } \\
\text { bertukar fikiran serta menyampaikan } \\
\text { apa yang boleh dan tidak boleh } \\
\text { dilakukan }\end{array}$ \\
\hline 4 & Atraksi Pembuka & $\begin{array}{l}\text { - Atraksi yang dilakukan oleh Barong } \\
\text { bangkung dan Barong bangkal }\end{array}$ \\
\hline 5 & Tradisi Omed-Omedan & $\begin{array}{l}\text { - Tradisi yang diikuti oleh muda-mudi } \\
\text { deng an tujuan bersila turahmi }\end{array}$ \\
\hline 6 & Upacara Penutup & $\begin{array}{l}\text { Ritual yang dilakukan di Pura } \\
\text { Banjar dipimpin oleh Jero } \\
\text { Pemangku }\end{array}$ \\
\hline
\end{tabular}


Masyarakat yang menganut agama Hindu khususnya Hindu-Bali memiliki tingkatan utama dalam persembahyangan yang dibagi menjadi tiga yaitu, Nista (tingkat sederhana), Madya (tingkat menengah), dan Utama (tingkat paling besar). Ketiga tingkatan tersebut memiliki makna yang sama namun dengan bagian yang berbeda-beda. Tingkatan sederhana hingga utama dibedakan berdasarkan tingkat ekonomi masyarakat yang akan melaksanakan upacara. Namun pada Tradisi Omed-Omedan terdapat beberapa sarana yang wajib ada dalam pelaksanaannya.

Tabel 2.

Sarana Tradisi Omed-Omedan

\begin{tabular}{|c|c|c|}
\hline No & Simbol-simbol & Keterangan \\
\hline 1 & Banten Pejati & $\begin{array}{l}\text { Sarana dalam upacara keagamaan dengan } \\
\text { tujuan memohon kelanc aran serta } \\
\text { keselamatan }\end{array}$ \\
\hline 2 & Bunga & $\begin{array}{l}\text { - Sarana persembahyangan symbol tulus } \\
\text { ikhlas } \\
\text { - Menggunakan beberapa jenis bunga } \\
\text { seperti pacar air, kembang seribu, dan } \\
\text { irisan tipis daun pandan yang bernama } \\
\text { rampe }\end{array}$ \\
\hline 3 & Dupa & $\begin{array}{l}\text { Wewangian yang berfungsi sebagai } \\
\text { perantara antara manusia dengan sang } \\
\text { pencipta } \\
\text { - Untuk persembahyang an masing-masing } \\
\text { individu menggunakan } 1 \text { buah dupa yang } \\
\text { sudah menyala } \\
\text { - Dupa juga diletakan di banten pejati } \\
\text { dengan jumlah } 3 \text { buah dengan dupa yang } \\
\text { sudah menyala }\end{array}$ \\
\hline 4 & Air & $\begin{array}{l}\text { - Sebagai pembersih secara spiritual } \\
\text { - Sebagai pemberi kesegaran secara fisik } \\
\text { - Air yang digunakan merupakan air bersih } \\
\text { yang diambil dari air yang mengalir yang } \\
\text { ada di Banjar Kaja Sesetan }\end{array}$ \\
\hline 5 & Bija & $\begin{array}{l}\text { Sebagai anugrah } \\
\text { - Merupakan beras yang sudah dicuci bersih } \\
\text { - Digunakan setelah usai melakukan } \\
\text { persembahyangan dan setelah dipercikan } \\
\text { tirtha } \\
\text { - Diletakan di dahi diantara kedua alis } \\
\text { beberapa butir, diletakan di leher tepat }\end{array}$ \\
\hline
\end{tabular}

Aktivitas komunikasi ritual yang terjadi selama pelaksanaan Tradisi Omed-Omedan yakni sebagai berikut:

\section{Situasi Komunikatif}

Situasi Komunikatif adalah konteks berlangsungnya komunikasi dalam sebuah proses komunikasi. Situasi komunikatif menggambarkan tempat berlangsungnya sebuah acara. Situasi dapat memiliki kesamaan dari segi tempat namun dengan setting yang berbeda seperti membuat acara disebuah tempat yang sama namun dengan tujuan acara yang berbeda. Dalam Tradisi Omed-Omedan situasi yang digambarkan mulai dari ritual yang dilakukan sebelum dilaksanakannya tradisi, Dharma Santi, persembahyangan bersama, puncak Tradisi Omed-Omedan, hingga ritual setelah pelaksanaan Tradisi Omed-Omedan situasi komunikatif yang tergambarkan dari rangkaian acara tersebut yaitu: Sakral, kegembiraan, suka cita, aura magis yang kental, dan keakraban. Situasi tersebut didukung dengan teriakan para peserta Tradisi Omed-Omedan dan syair-syair suci yang diucapkan oleh Jero Pemangku saat melakukan ritual. 


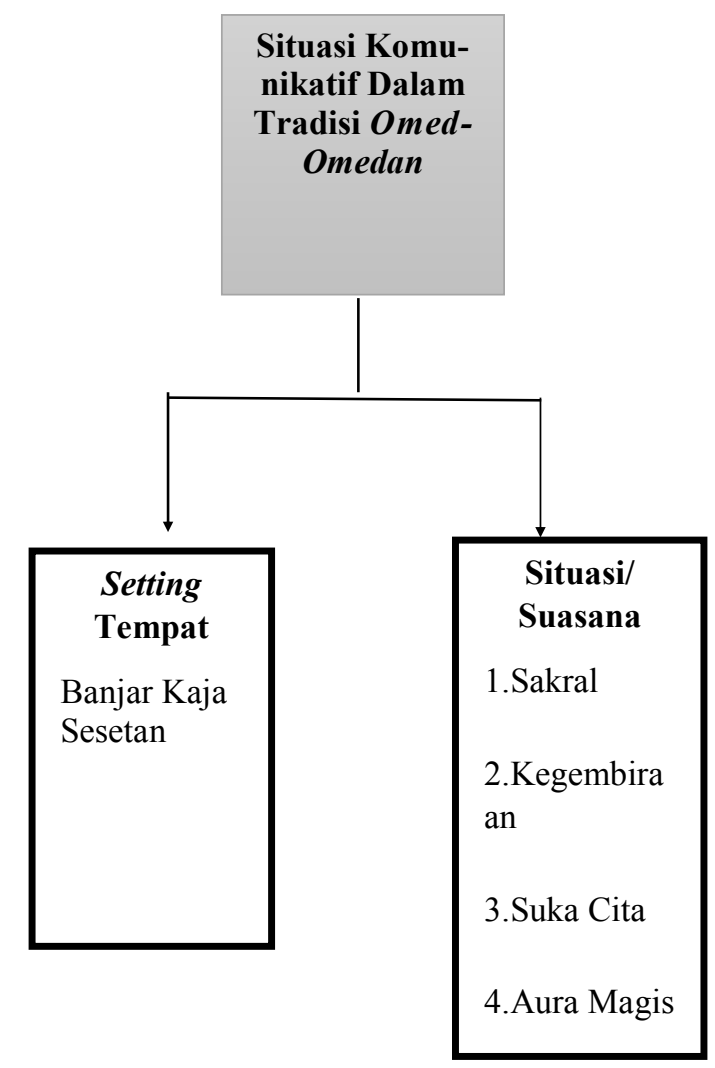

Gambar 1.

Bagan Situasi Komunikatif Tradisi Omed-Omedan

\section{Peristiwa Komunikatif}

Peristiwa Komunikatif adalah rangkaian peristiwa yang menggambarkan proses Tradisi OmedOmedan dari awal hingga berakhir. Peristiwa yang menjelaskan peserta Omed-Omedan yang harus berkumpul di Banjar Kaja Sesetan terlebih dahulu kemudian berkumpul untuk melakukan persembahyangan bersama yang dipimpin oleh Jero Pemangku Banjar Kaja Sesetan setelah Jero Mangku usai mengahturkan Banten Pejati dan ritual lainnya, setelah itu muda-mudi juga warga banjar dikumpulkan di aula Banjar Kaja untuk mendengarkan Dharma Santi yang disampaikan oleh pengurus banjar yang menyampaikan beberapa nasihat juga aturan terkait pelaksanaan tradisi oleh tetua Banjar Kaja Sesetan. Selanjutnya muda-mudi membuat barisan yang terdiri dari putra dan putri yang mana saling Tarik menarik satu sama lain yang merupakan puncak pelaksanaan Tradisi OmedOmedan, setelah berakhir beberapa peserta akan mengalami kerauhan yang kemudian akan digiring kedalam Pura Banjar Kaja Sesetan yang kemudian dilakukan beberapa ritual dengan menghaturkan Banten juga pemercikan tirtha kepada seuluruh peserta juga mendengarkan petuah serta keinginan dari beberapa peserta yang mengalami kerauhan. 


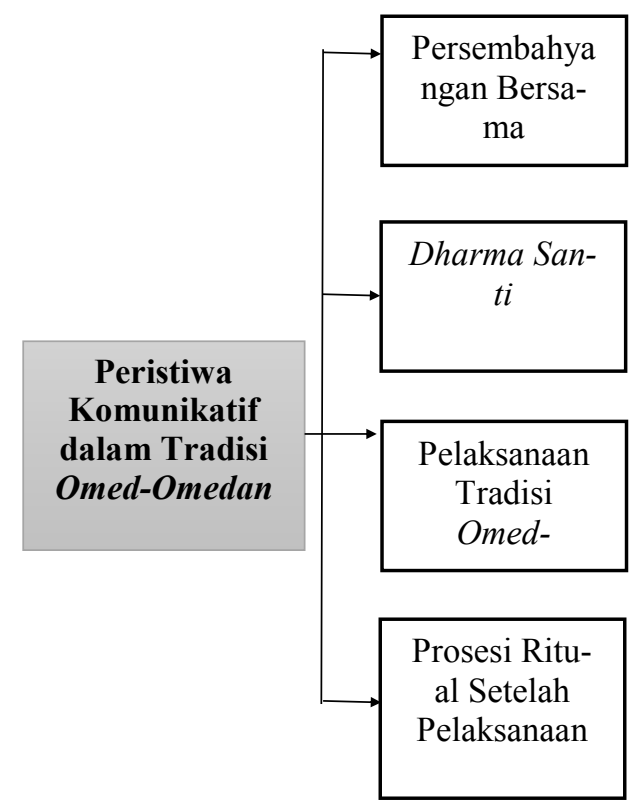

Gambar 2.

Bagan Peristiwa Komunikatif Tradisi Omed-Omedan

\section{Tindak Komunikatif}

Tindak Komunikatif merupakan fungsi interaksi tunggal. Pada Tradisi Omed-Omedan terdapat tindak komunikatif yang terdiri dari komunikasi verbal dan komunikasi non verbal. Yang mana komunikasi verbal diungkapkan melalui lisan atau tulisan sedangkan komunikasi non verbal diungkapkan secara simbolik. Dalam prakteknya komunikasi verbal berupa perintah, nasihat dan wejangan, serta doa dan syair-syair suci. Seperti contohnya dalam kegiatan Dharma Santi disampaikan nasihat serta wejangan dari pengurus Banjar Kaja serta tetua kepada seluruh warga banjar untuk introspeksi diri terkait dengan perbuatan bermasyarakat yang dilakukan apakah sudah sesuai dengan ajaran agama tau belum. Sedangkan perintah disampaikan oleh tetua kepada peserta Tradisi Omed-Omedan untuk melakukan tradisi sesuai dengan aturan dan pakem yang ada agar tidak menimbulkan kesalahpahaman di masyarakat. Doa dan syair-syair suci dilantunkan atau diucapak oleh Jero Pemangku Banjar Kaja dalam melakukan ritual keagamaan terkait pelaksanaan tradisi untuk menghaturkan sesajen atau banten kehadapan Tuhan Yang Maha Esa. Selain komunikasi verbal terdapat contoh dalam beberapa kegiatan yang menggunakan komunikasi non verbal yaitu berupa symbol-simbol dalam pelaksanaan Tradisi Omed-Omedan seperti penggunaan Banten Pejati sebagai lambang ketulus ikhlasan juga permohonan agar selalu diberkati juga selalu dalam lindungannya. Selain itu terdapat gerak tubuh yang dilakukan oleh beberapa orang yang memiliki arti yang dapat dimengerti oleh para peserta. 


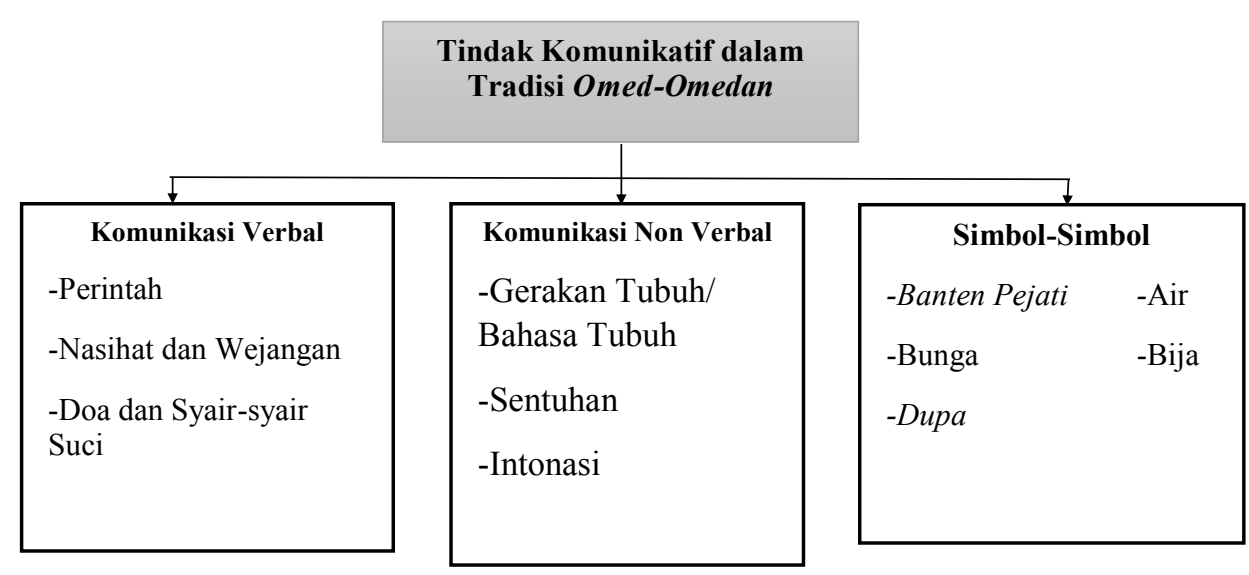

Gambar 3.

Bagan Tindak Komunikatif Tradisi Omed-Omedan

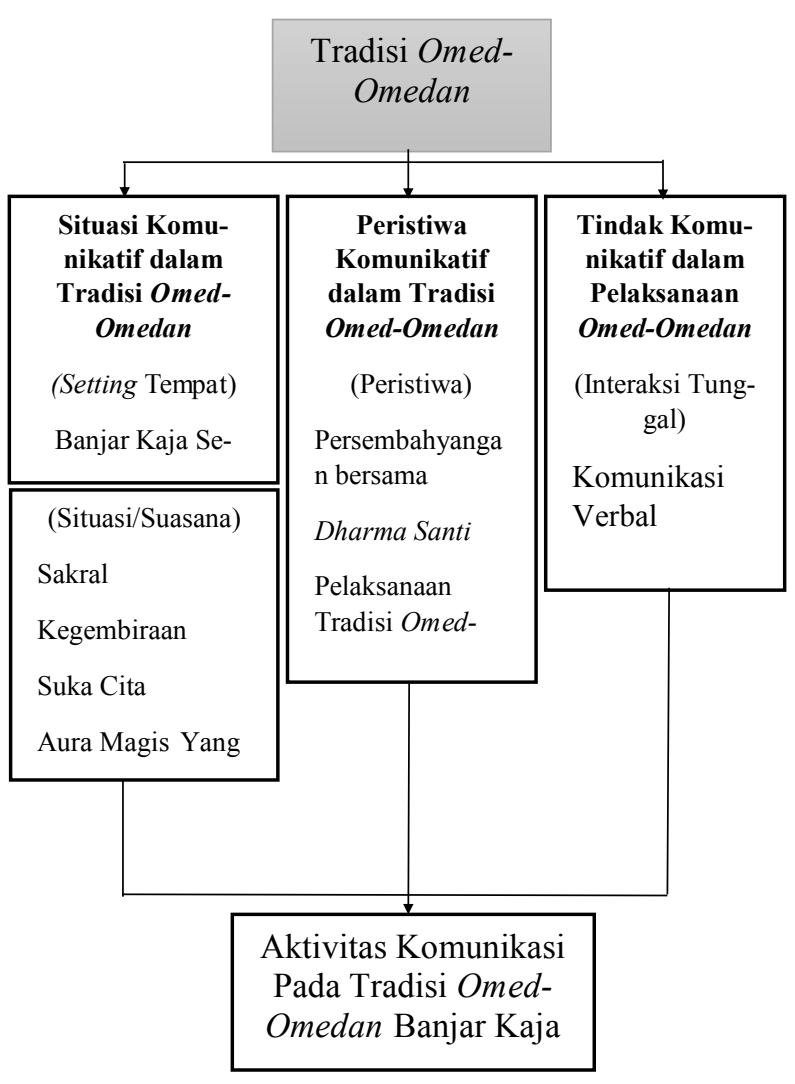

Gambar 4.

Model Aktivitas Komunikasi Tradisi Omed-Omedan 


\section{Simpulan}

Situasi Komunikatif merupakan sebuah gambaran tempat dilangsungkannya sebuah acara atau kegiatan. Dalam hal ini Tradisi Omed-Omedan menggunakan setting tempat di halaman Banjar Kaja Sesetan khusus pada tahun 2020 dikarenakan pandemic yang sedang melanda sehingga tradisi ini dilaksanakan secara tertutup, namun biasanya dari tahun ke tahun tradisi ini dilaksanakan di depan Banjar Kaja Sesetan tepatnya di jalan raya. Dalam pelaksanaannya situasi komunikatif yang tergambar adalah sacral, kegemebiraan, suka cita, aura magis yang kental dan keakraban.

Peristiwa Komunikatif dalam Tradisi Omed-Omedan menjelaskan rangkaian kegiatan yang dilakukan secara berurutan dari awal prosesi hingga akhir. Tradisi ini diawali dengan persembahyangan bersama setelah Jero Pemangku usai menghaturkan Banten Pejati serta sarana lainnya, Dharma Santi, puncak acara Tradisi Omed-Omedan, prosesi ritual setelah pelaksanaan Tradisi Omed-Omedan.

Tindak Komunikatif merupakan fungsi interaksi tunggal yang mana berupa pernyataan, permohonan, perintah ataupun perilaku non verbal yang dilakukan oleh individu dalam berinteraksi. Dalam Tradisi Omed-Omedan terdapat tindak komunikatif yang dilakukan dalam bentuk komunikasi verbal dan komunikasi non verbal. Pada pelaksanaannya komunikasi verbal dilakukan dalam bentuk perintah, wejangan dan nasihat, doa dan syair-syair suci. Sedangkan dalam bentuk komunikasi non verbal dilakukan melalui gerakan tubuh/Bahasa tubuh, sentuhan dan intonasi. Selain itu terdapat penggunaan beberapa symbol yaitu penggunaan Banten Pejati, bunga, dupa, air dan bija.

\section{Daftar Pustaka}

Cahyadinata, I. P. A. A. (2013). Perspektif Sosio-Budaya Dan Religius Terhadap Tradisi Omed-Omedan Di Banjar Kaja, Kelurahan Sesetan, Kota Denpasar, Bali. Ejornal Undiknas. https://doi.org/10.1017/ CBO9781107415324.004

Kuswarno, E. (2011). Etnografi Komunikasi: Pengantar dan contoh penelitiannya (cetakan kedua). Bandung: Widya Padjajaran.

Mulyana, D. (2013). Ilmu Komunikasi Suatu Pengantar. Bandung: PT. Remaja Rosdakarya.

Supartika, P. (2018). Ini 3 Tradisi Asli yang Mesti Ditonton Saat Berada di Kota Denpasar Artikel ini telah tayang di tribun-bali.com dengan judul TRIBUN WIKI: Ini 3 Tradisi Asli yang Mesti Ditonton Saat Berada di Kota Denpasar. Bali.Tribunnews. https://bali.tribunnews.com/2018/12/10/tribun-wiki-ini-3tradisi-asli-yang-mesti-ditonton-saat-berada-di-kota-denpasar?page-4

Wahyuningsih, A. (2019). Bukan tradisi ciuman asal, ini 5 fakta Omed-omedan di Bali. Brilio.Net. https:// www.brilio.net/wow/bukan-tradisi-ciuman-asal-ini-4-fakta-omed-omedan-di-bali-190307g.html

Yanti, Putu Feby Sukma \& Nurhayati, I. K. (2018). Aktivitas Komunikasi Pada Ritual Keagamaan (Studi Etnografi Komunikasi Dalam Ritual Tumpek Wariga Di Bali). https://openlibrary.telkomuniversity.ac.id/ home/catalog/id/142468/slug/aktivitas-komunikasi-pada-ritual-keagamaan-studi-etnografi-komunikasidalam-ritual-tumpek-wariga-di-bali-.html 